\title{
EFFECT OF L-TYROSINE ON GROWTH PERFORMANCE, AGE OF SEXUAL PUBERTY, SEMEN QUALITY AND TESTOSTERONE LEVEL IN FRIEZIAN BULLS
}

\author{
Abu El-Hamd, M. A. and M. S. Sayah \\ Animal Production Research Institute, Agricultural Research Center, Dokki, Giza, Egypt \\ Email: (abuelhamd68@yahoo.com)
}

\section{SUMMARY}

Thirty Friesian bull calves averaged $8.5 \pm 0.16$ month of age and $195 \pm 15 \mathrm{~kg}$ body weight were used in this study. All bulls were fed similar diets. The bulls were divided into three similar groups (10 each), according to their weight and age. Bulls in the $1^{\text {st }}$ group were considered as control (G1). while those in the $2^{\text {nd }}$ group were received single oral dose from L-tyrosine $(50 \mathrm{~g} / \mathrm{bull})$ at 8.5 months of age $(G 2)$. Bulls in the $3^{\text {rd }}$ group were received two oral doses from L-tyrosine $(50 \mathrm{~g} / \mathrm{bull})$ at 8.5 and 10.5 months of age (G3). The results revealed that L-tyrosine treatment increased $(P<0.01)$ the live body weight $(L B W)$ in $G 3$ and $G 2$ compared to G1 at 12 month, first appearance of spermatozoa, sexual puberty, and at 24 months of age. Age at first appearance of spermatozoa and puberty age were $(P<0.001)$ earlier by about 1.2 and 1.5 and 0.9 and 1.7 months, respectively, for bulls in $G 2$ and $G 3$ than the control. Changes in testosterone concentration during the study period were higher $(P<0.05)$ in $G 3$ and $G 2$ than in $G 1$. L-tyrosine increased $(P<0.01)$ percentages of progressive motility and livability of spermatozoa, and sperm cell concentration compared to control at first appearance of spermatozoa, puberty, and at 24 months of age. In general, semen quality improved $(P<0.01)$ at 24 month of age as compared to puberty age. Sperm motility and livability and sperm cell concentration significantly increased $(P<0.01)$ with advancing age in all groups. Morphology defects in the head of spermatozoa were lower $(P<0.05)$ in $G 2$ and $G 3$ than in $G 1$ at first appearance of spermatozoa, sexual puberty and at 24 months of age. Also the proximal droplets were lower $(P<0.05)$ in $G 2$ and $G 3$ than in $G 1$ at puberty and at 24 months of age. There was a significant increase in number of normal sperm cells with age advancement as well as significant decreases in proximal droplets and head defects. The present results indicated that treated bulls by one or two doses of L-tyrosine (50 gm/bull calves) induced an improvement of growth performance, earlier sexual puberty and improved semen quality of Friesian bull.

Keywords: Friesian bull, L-tyrosine, puberty, testosterone and semen quality

\section{INTRODUCTION}

Enhancement the release of sex hormones was suggested to improve growth and reproductive performance. The amino acid (L-Tyrosine) is involved in formation of catecholamine from adrenal gland and thyroxin from thyroid gland (Hammerl and Russe, 1987a). In this respect, Abo-Elroos (1992) reported that L-Tyrosine possessed to improve the reproductive efficiency in rabbits, through enhancing the release of sex hormones. Gabr (2009) found that the double oral dose from L-Tyrosine $(100 \mathrm{mg} / \mathrm{kg}$ live body weight) at 15 days-interval induced early puberty in rabbit bucks.

Exogenous tyrosine decreased age at puberty in rats (Hammerl and Russe, 1987b); increased litter size in rats (Hammerl and Muller, 1988) and swine (Hammerl and Russe, 1987a); increased LH pulse frequency in growth-restricted lambs (Hall et al., 1992); induced follicular growth, estrus, and ovulation in anovulatory dairy cows (Wetzel, 1985; Hammerl, 1986 and Munsterer, 1987); and improved expression of estrus in sows (Hammerl and Russe, 1987a). The amino acid tyrosine, may be involved in stimulating $\mathrm{GnRH}$ release because availability of tyrosine influences on synthesis of norepinephrine (Wurtman et al., 1981; Gibson and Wurtman, 1986 and Acworth et al., 1988), a neurotransmitter that stimulates GnRH release (Ramirez et al., 1984 and Terasawa et al., 1988).

Tyrosine hydroxylase is an enzyme involved in the synthesis of catecholamine (Nagatsu et al., 1964). Alonso et al. (1982) found that production of the tyrosine hydroxylase is controlled by tyrosine level in the blood.

Dopamine is an important hypothalamic catecholamine activating the release of growth hormone (Muller, 1973). Catecholamine stimulates the hypothalamus to release $\mathrm{GnRH}$ via adrenergic receptor mechanism (Arthur, 1989). Release of GnRH stimulates anterior pituitary gland to release FSH and LH, which control folliculogenesis and spermatogenesis.

The aim of this experiment was to study the effect of L-tyrosine on characterization reproductive development, testosterone level, age of puberty and semen quality of Frisian bull calves.

\section{MATERIALS AND METHODS}

The present study was carried out at Sakha Animal Production Research Station, Sakha, Kafer 
El-Sheikh Governorate, Egypt, belonging to the Animal Production Research Institute.

\section{Animals and management:}

Thirty Friesian bull calves averaging $8.5 \pm 0.16$ month of age and $195 \pm 15 \mathrm{~kg}$ live body weight (LBW)were divided into three equal groups (10 each), according to their LBW and age. All bulls were fed similar diets. Bulls in the $1^{\text {st }}$ group were considered as a control group (G1). Bulls in the $2^{\text {nd }}$ group were received single oral dose from L-tyrosine ( $50 \mathrm{~g} / \mathrm{bull})$ at 8.5 months of age (G2), while bulls in the $3^{\text {rd }}$ group were received two oral dose from Ltyrosine $(50 \mathrm{~g} / \mathrm{bull})$ at 8.5 and 10.5 months of age (G3). All bulls were judged to be free of physical defects and diseases and had normal external genitalia. Animals were kept freely under semi-open sheds and were fed according to the recommendations of Animal Production Research Institute (APRI, 2002) throughout the experimental period.

\section{Feeding system and management}

Concentrate feed mixture (CFM) used in feeding the bulls of all groups was composed of $37.5 \%$ yellow corn, $20 \%$ soybean meal, $15 \%$ corn gluten, $22.5 \%$ wheat bran, $3 \%$ molasses, $0.5 \%$ premix (mixture vitamins and minerals) and $1.5 \%$ common salt. Rice straw and fresh berseem (during winter season) or corn silage (during summer season) according to the recommendation of the APRI, (2002).

\section{Experimental procedures}

Throughout the experimental period, semen was collected from all bulls twice weekly using an artificial vagina from 10 up to 24 month of age. Immediately after collection, the percentage of progressive sperm motility, livability and abnormalities of spermatozoa, as well as, sperm cell concentration were evaluated according to Barth (2002). Abnormal sperm were classified into four categories according to descriptions used for bovine evaluations (Barth, 2000), head defects, s midepiece defects, proximal and tail defects. The bull was considered at the age of puberty when produced an ejaculate containing minimum of $50 \times 10^{6}$ sperm cells having at least $10 \%$ progressive motility according to Wolf et al. (1965).

Blood samples were monthly collected in clean test tubes via the jugular vein and centrifuged at 3000 $\mathrm{rp} / \mathrm{m}$ for 10 minutes to separate blood serum which stored at $-20 \mathrm{oC}$ for determination of testosterone concentration in blood serum.

Total serum testosterone assay was conducted by radioimmune assay using - Pontex 335 kit $\left(\mathrm{I}^{125}\right)$. Types of testosterone assayed were (A) total testosterone (direct extraction-coated tubes) and (B) free testosterone. According to the instructions of the producing company (Pantex Santa Monica), the solvents used in this assay break the protein binding during extraction process. The standard curve of testosterone ranged between 0.1 and $25.6 \mathrm{ng} / \mathrm{ml}$.

\section{Statistical analysis}

Results (age and LBW) were statistically analyzed according to Snedecor and Cochran (1980). A factorial design (3 groups $\mathrm{x} 4$ ages) was used and the statistical model was:

Where:

$$
Y_{i j k}=U+A_{i}+B_{j}+A B_{i j}+e_{i j k} .
$$

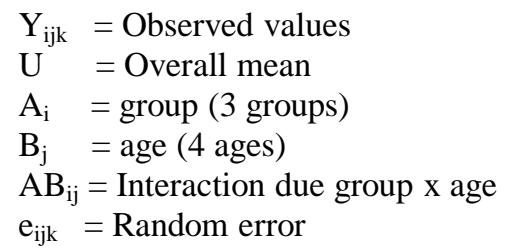

The significant differences among means were tested using Duncan Multiple Range Test (Duncan, 1955). The percentage values of semen characteristics were subjected to arcsine transformation before performing the analysis of variance. Means were presented after being recalculated from the transformed values to percentages.

\section{RESULTS AND DISCUSSION}

Results presented in Table (1) revealed that Ltyrosine treatment has significantly positive effect $(\mathrm{P}<0.01)$ on live body weight $(\mathrm{LBW})$ in $\mathrm{G} 3$ and $\mathrm{G} 2$ than in G1 at the studied four ages, 12 month of age, first appearance of spermatozoa, puberty, and 24 months of age. Increase of LBW after treatment with tyrosine is mainly due to production of tyrosine hydroxylase enzyme. This enzyme involved in the synthesis of catecholamine (Nagatsu et al., 1964). Dopamine is an important hypothalamic catecholamine activating the release of growth hormone (Muller, 1973). Also it has been found that catecholamine stimulates the hypothalamus to release GnRH via adrenergic receptor mechanism (Arthur, 1989). Release of GnRH stimulates anterior pituitary gland to secrete FSH and LH, which control the spermatogenesis (Hafez, 1993 and Salisbury et al., 1978).

Age at first appearance of spermatozoa and puberty were significantly $(\mathrm{P}<0.001)$ earlier by about 1.2 and 1.5 and 0.9 and 1.7 months, respectively, for bulls in G2 and G3 groups than the control group (Table 1 and Figure 1). The present results were agreed with Noseir et al. (2007) results who found that, L-tyrosine induced puberty in the rabbit two weeks earlier than control, and Grasa et al. (2009) who reported that L-tyrosine induced puberty in treated rams earlier than the untreated rams. 
Table 1. Effect of L-tyrosine on age, body weight and serum testosterone level (Mean \pm S.E.) at first appearance of spermatozoa, puberty, and 12 and 24 months of age

\begin{tabular}{|c|c|c|c|c|c|}
\hline Items & Group & 12 months & First sperm & Puberty* & 24 months \\
\hline \multirow{4}{*}{ Body weight (kg) } & G1 & 226 & 247 & $291^{\mathrm{b}}$ & $459^{\mathrm{b}}$ \\
\hline & G2 & 246 & 261 & $312^{\mathrm{a}}$ & $481^{\mathrm{a}}$ \\
\hline & G3 & 262 & 271 & $311^{\mathrm{a}}$ & $498^{\mathrm{a}}$ \\
\hline & S.E. & \pm 12.50 & \pm 13.5 & \pm 7.20 & \pm 11.5 \\
\hline \multirow{4}{*}{ Age (months) } & G1 & - & $13.8^{\mathrm{a}}$ & $15.5^{\mathrm{a}}$ & - \\
\hline & G2 & - & $12.6^{\mathrm{b}}$ & $14.6^{\mathrm{ab}}$ & - \\
\hline & G3 & - & $12.3^{\mathrm{b}}$ & $13.8^{\mathrm{b}}$ & - \\
\hline & S.E. & - & \pm 0.24 & \pm 0.51 & - \\
\hline \multirow{4}{*}{ Testosterone (ng/ml) } & G1 & $6.25^{\mathrm{b}}$ & $8.56^{\mathrm{b}}$ & $7.27^{\mathrm{b}}$ & $6.54^{\mathrm{b}}$ \\
\hline & G2 & $7.23^{\mathrm{a}}$ & $9.57^{\mathrm{a}}$ & $8.56^{\mathrm{a}}$ & $7.69^{\mathrm{a}}$ \\
\hline & G3 & $7.95^{\mathrm{a}}$ & $9.68^{\mathrm{a}}$ & $8.56^{\mathrm{a}}$ & $8.01^{\mathrm{a}}$ \\
\hline & S.E. & \pm 0.25 & \pm 0.32 & \pm 0.27 & \pm 0.17 \\
\hline
\end{tabular}

*Sexual puberty was recorded when the first ejaculate contained a minimum of $50 \times 10^{6}$ sperm cells and had at least $10 \%$ progressive motility (Wolf et al., 1965).

a and b: Means within the same column with different superscripts are significantly different at $(\mathrm{P}<0.05)$.

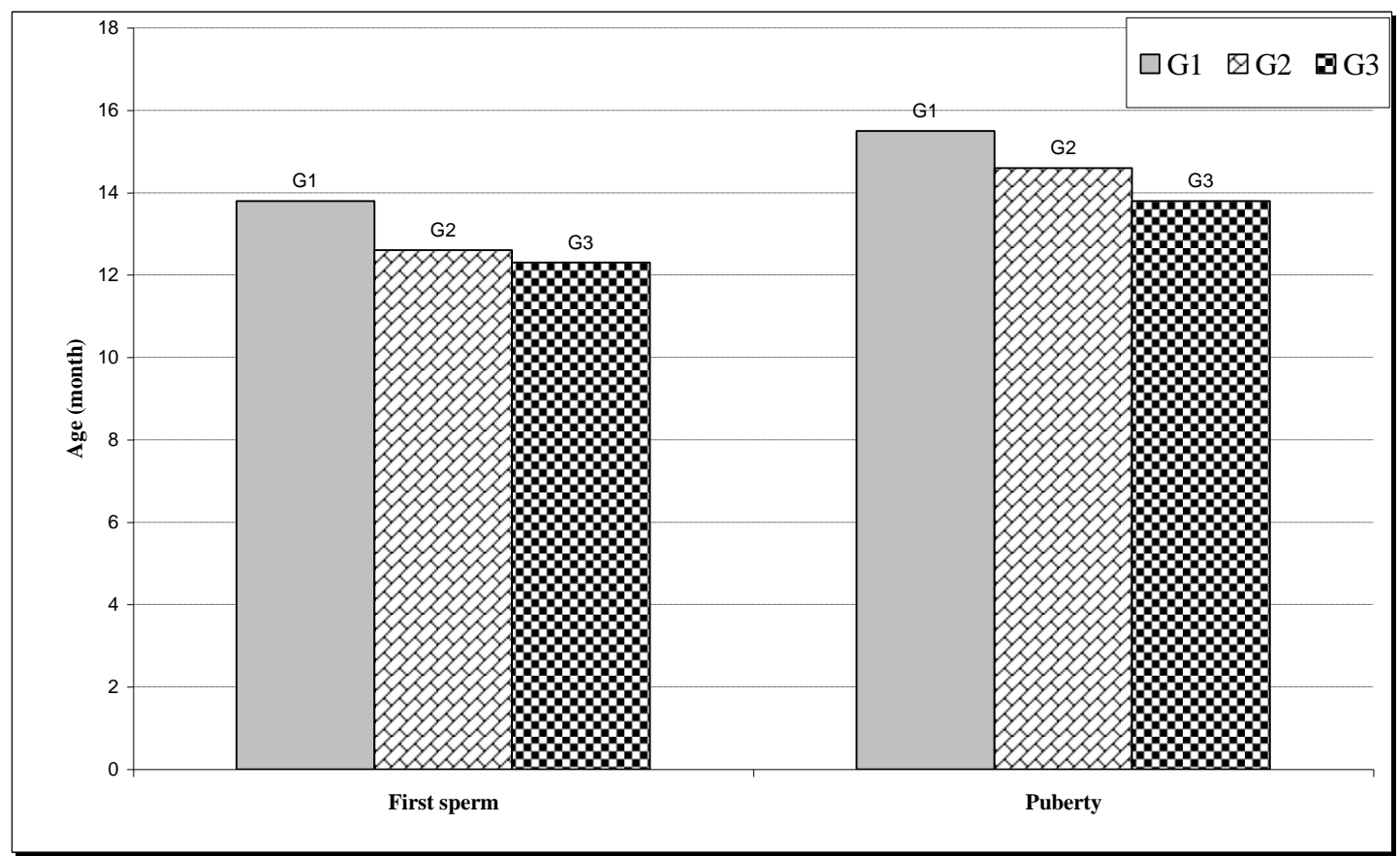

Figure 1. Effect of L-tyrosine on age at first sperm and sexual puberty in bull calves

Overall changes in testosterone concentrations during the study period were significantly higher in G3 and G2 than in G1 at 12 month, first appearance of spermatozoa, puberty, and at 24 months of age (Table 1 and Figure 2). The present results are agreed with Saad et al. (2005) who found that serum testosterone concentrations increased significantly in rabbit treated by L-tyrosine compared to control. Testosterone concentration levels increased with advancing age (Figure 1). In growing male cattle, serum testosterone increased in linear fashion as the testes develop and spermatogenesis progresses (McCarthy et al., 1979 and Schams et al., 1981).

Data presented in Table (2) shows that bulls treated with L-tyrosine increased significantly $(\mathrm{P}<0.01)$ percentages of progressive motility and livability of spermatozoa and sperm concentration compared to the control at first appearance of spermatozoa, puberty, and 24 months of age. In general, semen quality of the bulls showed significant $(\mathrm{P}<0.01)$ improvement at 24 months compared to puberty age. However, ejaculate volume did not significantly affected by treatment groups. Also, sperm motility and livability, as well as, sperm cell concentration were significantly $(\mathrm{P}<0.01)$ increased with advancing age in all groups. Sperm cell concentration was increased by advancement of age (Figure 3). The present findings are in agreement with those reported by Helbig et al. (2007) who found that the first production of sperm cells occurred at approximately 14 months of age (13-15 months), but almost no spermatozoa exhibited normal morphology at this age. The earliest sperm were extremely malformed but by the second collection, cellular morphology began to improve, the greatest improvements occurring from 19 to 23 months of age. Additionally, the appearance of first sperm in beef bulls is known to be earlier, at 8-12 
months of age and, as bulls advance in age from 13 to 24 months, the percentage of morphologically normal sperm cells increases (Lunstra and Echternkamp, 1982 and Arteaga et al., 2001). It was reported that exogenous L-tyrosine increased frequency of $\mathrm{LH}$ pulses (Hall et al., 1992) this conclusion may explain the improvement of semen quality in L-tyrosine treated bulls in the present study.

Table 2. Effect of L-tyrosine on semen characteristics (Mean \pm S.E.) at first appearance of spermatozoa, puberty, and at 24 months of age

\begin{tabular}{|c|c|c|c|c|}
\hline Items & Group & First sperm & Puberty* & 24 months \\
\hline & G1 & 1.6 & 2.4 & 2.42 \\
\hline Ejaculate volume (ml) & $\begin{array}{r}\text { G2 } \\
\text { G3 } \\
\text { S.E. }\end{array}$ & $\begin{array}{c}2.1 \\
2.2 \\
\pm 0.2\end{array}$ & $\begin{array}{c}2.9 \\
3.1 \\
\pm 0.32\end{array}$ & $\begin{array}{c}2.75 \\
3.03 \\
\pm 0.25\end{array}$ \\
\hline & G1 & $36.5^{\mathrm{b}}$ & $554^{\mathrm{b}}$ & $1087^{\mathrm{b}}$ \\
\hline $\begin{array}{l}\text { Sperm cell concentration } \\
\left(\times 10^{6} / \mathrm{ml}\right)\end{array}$ & $\begin{array}{r}\text { G2 } \\
\text { G3 } \\
\text { S.E. }\end{array}$ & $\begin{array}{l}41.5^{\mathrm{ab}} \\
44.5^{\mathrm{a}} \\
\pm 2.2\end{array}$ & $\begin{array}{l}628^{\mathrm{ab}} \\
747^{\mathrm{a}} \\
\pm 60\end{array}$ & $\begin{array}{c}1242^{\mathrm{ab}} \\
1347^{\mathrm{a}} \\
\pm 70\end{array}$ \\
\hline & G1 & $5.2^{\mathrm{b}}$ & 52.45 & $76.51^{\mathrm{b}}$ \\
\hline Sperm mass motility (\%) & $\begin{array}{r}\text { G2 } \\
\text { G3 } \\
\text { S.E. }\end{array}$ & $\begin{array}{c}7.3^{\mathrm{a}} \\
7.9^{\mathrm{a}} \\
\pm 0.19\end{array}$ & $\begin{array}{l}58.54 \\
60.39 \\
\pm 4.5\end{array}$ & $\begin{array}{c}81.5^{\mathrm{ab}} \\
87.47^{\mathrm{a}} \\
\pm 3.6\end{array}$ \\
\hline & G1 & $29.5^{\mathrm{b}}$ & $45.51^{\mathrm{b}}$ & $65.24^{\mathrm{b}}$ \\
\hline Live sperm (\%) & $\begin{array}{r}\text { G2 } \\
\text { G3 } \\
\text { S.E. }\end{array}$ & $\begin{array}{l}32.5^{\mathrm{a}} \\
33.4^{\mathrm{a}} \\
\pm 0.6\end{array}$ & $\begin{array}{c}52.34^{\mathrm{ab}} \\
54.25^{\mathrm{a}} \\
\pm 2.4\end{array}$ & $\begin{array}{c}74.25^{\mathrm{ab}} \\
78.24^{\mathrm{a}} \\
\pm 4.3\end{array}$ \\
\hline
\end{tabular}

*Sexual puberty was recorded when the first ejaculate contained a minimum of $50 \times 10^{6}$ sperm cells and had at least $10 \%$ progressive motility (Wolf et al., 1965).

a and $b$ : Means within the same column with different superscripts are significantly different at $(\mathrm{P}<0.05)$.

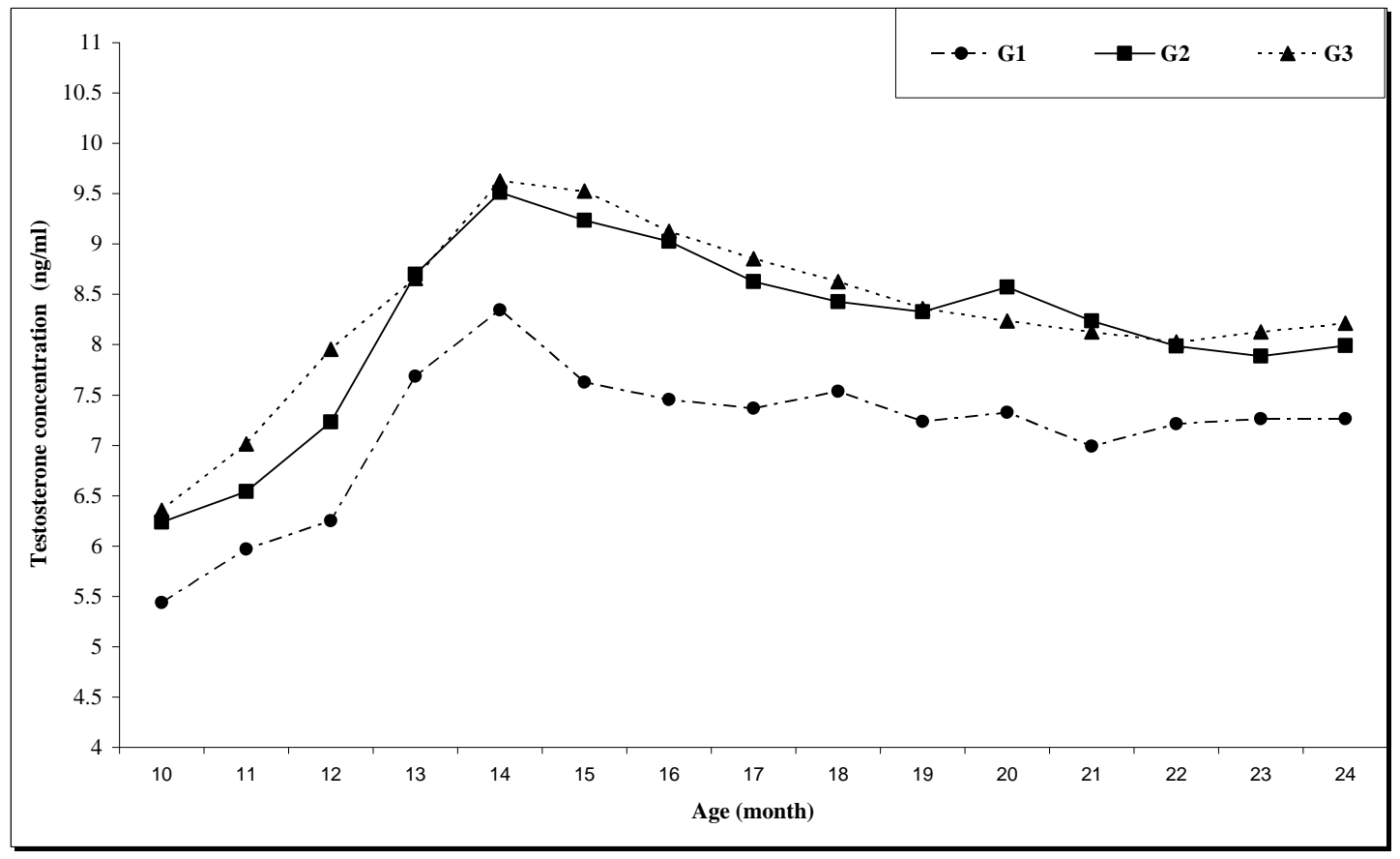

Figure 2. Effect of L-tyrosine on serum testosterone concentration in bull calves 


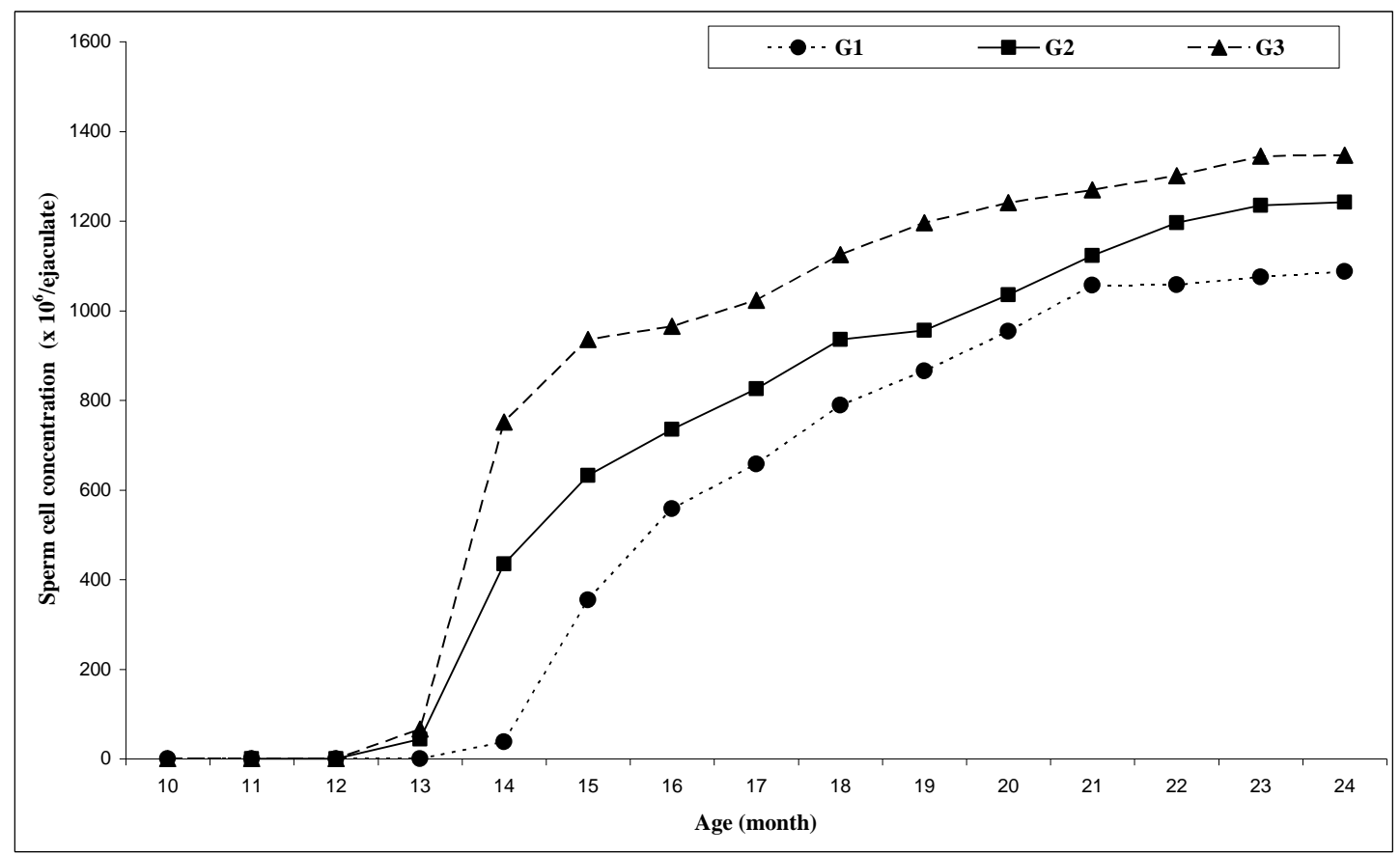

Figure 3. Effect of L-tyrosine on sperm cells concentration in bulls

Table 3. Effect of L-tyrosine on sperm morphology (\%) (Mean \pm S.E.) at first appearance of spermatozoa, puberty, and at 24 months of age

\begin{tabular}{|c|c|c|c|c|}
\hline Sperm morphology (\%) & Group & First sperm & Puberty* & 24 months \\
\hline \multirow{4}{*}{ Normal } & G1 & $6.21^{\mathrm{b}}$ & $22.52^{\mathrm{b}}$ & $71.81^{\mathrm{b}}$ \\
\hline & G2 & $11.18^{\mathrm{a}}$ & $29.87^{\mathrm{a}}$ & $79.54^{\mathrm{a}}$ \\
\hline & G3 & $12.75^{\mathrm{a}}$ & $30.15^{\mathrm{a}}$ & $81.42^{\mathrm{a}}$ \\
\hline & S.E. & \pm 1.2 & \pm 1.3 & \pm 1.5 \\
\hline \multirow{4}{*}{ Head defects } & G1 & $51.82^{\mathrm{a}}$ & $42.85^{\mathrm{a}}$ & $12.57^{\mathrm{a}}$ \\
\hline & G2 & $47.4^{\mathrm{b}}$ & $39.1^{\mathrm{b}}$ & $9.7^{\mathrm{b}}$ \\
\hline & G3 & $47.1^{\mathrm{b}}$ & $39.2^{\mathrm{b}}$ & $8.1^{\mathrm{b}}$ \\
\hline & S.E. & \pm 1.2 & \pm 1.2 & \pm 0.6 \\
\hline \multirow{4}{*}{ Midpiece defects } & G1 & 15.2 & 14.13 & $7.5^{\mathrm{a}}$ \\
\hline & G2 & 14.7 & 12.9 & $5.26^{\mathrm{b}}$ \\
\hline & G3 & 14.6 & 12.7 & $5.28^{\mathrm{b}}$ \\
\hline & S.E. & \pm 0.8 & \pm 0.7 & \pm 0.4 \\
\hline \multirow{4}{*}{ Tail defects } & G1 & 7.23 & 7.3 & 5.9 \\
\hline & G2 & 8.92 & 7.63 & 4.5 \\
\hline & G3 & 8.35 & 7.15 & 4.3 \\
\hline & S.E. & \pm 0.6 & \pm 0.8 & \pm 0.7 \\
\hline \multirow{4}{*}{ Proximal droplets } & G1 & 19.54 & $13.2^{\mathrm{a}}$ & $2.24^{\mathrm{a}}$ \\
\hline & G2 & 17.8 & $10.5^{\mathrm{b}}$ & $1.0^{\mathrm{b}}$ \\
\hline & G3 & 17.2 & $10.8^{b}$ & $0.9^{\mathrm{b}}$ \\
\hline & S.E. & \pm 0.8 & \pm 0.7 & \pm 0.4 \\
\hline
\end{tabular}

$\mathrm{a}$ and b: Means within the same column with different superscripts are significantly different at $(\mathrm{P}<0.05)$.

*Sexual puberty was recorded when the first ejaculate contained a minimum of $50 \times 10^{6}$ sperm cells and had at least $10 \%$ progressive motility (Wolf et al., 1965).

Data presented in Table (3) shows that normal sperm morphology was significantly $(\mathrm{P}<0.05$ higher in G2 and G3 than the control group at first sperm, puberty and 24 months of age. However, the defects in sperm head morphology were significantly $(\mathrm{P}<0.05)$ lower in $\mathrm{G} 2$ and $\mathrm{G} 3$ than in the control group at first appearance of spermatozoa, puberty and 24 months of age. However, proximal droplets were significantly $(\mathrm{P}<0.05)$ lower in G2 and G3 than in the control group at puberty and at 24 months of age. Midpiece defects were significantly $(\mathrm{P}<0.05)$ lower in L-tyrosine groups than in control group at 24 month of age, but no significant differences at first appearance of spermatozoa and puberty of age.

The present results are in agreement with Ho and Suarez (2001) who proposed that, L-tyrosine induced puberty in small ruminants with an improvement of semen characters. The increase in protein tyrosine associated with improvement of puberty and semen characteristics in rams (Kulanand and Shivaji, 2001 and Baker et al., 2004). 
The same trend was observed by Perez-Pe et al. (2002) and Grasa et al. (2009); they demonstrated that protein tyrosine improved puberty, fertility and semen characteristics in rams.

Changes in semen morphology were significantly decreased in proximal cytoplasmic droplets $(\mathrm{P}<0.01)$ and head defects $(\mathrm{P}<0.05)$ with advancing bull age, but no significant changes in midpiece and tail defects Table (3). These results are similar to that by Helbig et al. (2007). They found that an increase in number of normal sperm cells and a decrease in proximal droplets and head defects with increasing bull age.

\section{CONCLUSION}

In conclusion, an oral single or two dose of Ltyrosine (50 g/bull calves) showed an improvement in growth performance, induced earlier puberty and had beneficial effects on semen quality of Friesian bulls calves.

\section{REFERENCES}

Abo-Elroos, M.A., 1992. Effect of tyrosine on the pituitary and gonads of rabbits in relation to sexual maturity. M. V. Sc. Thesis, Zagazig Univ. FAC., Vet. Med. Moshtoher, Banha.

Acworth, I.N., M.J. During, and R.J. Wurtman, 1988. Tyrosine: Effects on catecholamine release. Brain Res. Bull. 21:473-477.

Alonso, R., C.J. Gibson R.J. Wurtman and L. Pricto, 1982. "Elevation of Urinary Catecholamines and Their Metabolites Following Tyrosine Administration in Humans, "Biological Psychiatry 17:781-790.

APRI., 2002. Recommendation of the Animal Production Research Institute.

Arteaga, A., M. Baracaldo and A.D. Barth, 2001. The proportion of beef bulls in western Canada with mature spermiograms at 11 to 15 months of age. Can. Vet. J. 4: 783-787.

Arthur, R.J., 1989. Veterinary reproduction and obstetrics. Bailiere Tindall, London. $6^{\text {th }}$ ed.

Baker M.A., L. Hetherington, H. Ecroyd, S.D. Roman and R.J. Aitken, 2004. Analysis of the mechanisms by which calcium negatively regulates the tyrosine phosphorylation cascade associated with sperm capacitation. J. Cell. Sci., 117: 211-222

Barth, A.D., 2002. Bull breeding soundness evaluation. The western Canadian association of bovine practitioners.

Barth, A.D., 2000. Bull Breeding Soundness Evaluation. Western Canadian Association of Bovine Practitioners, Saskatoon, Sask., Canada.

Duncan, D.B., 1955. Multiple rang and multiple F test. Biometrics, 11: 1-42.

Gabr, Sh. A., 2009. The relay of sexual puberty in rabbit male by $\mathrm{L}$-tyrosine or carnitine treatment. J. Agric. Res., Kafrelsheikh Univ., 35: 56-68.
Gibson, C.J., and R.J. Wurtman, 1986. Physiological control of brain norepinephrine synthesis by brain tyrosine concentrations. Life Sci., 22: 1399-1406.

Grasa, P., Cebrian-Perez, J.A. and T. MuinoBlannco, 2009. Signal transduction mechanisms involved in in vitro ram sperm capacitattion. Reprod., 132: 721-732.

Hafez E.S.E., 1993. Reproduction in farm animals, $6^{\text {th }}$ edition, Lea\& Febiger, Philadelphia, 94-113.

Hall, J.B., K.K. Schillo, S.M. Hileman, and J.A. Boling, 1992. Does tyrosine act as a nutritional signal mediating the effects of increased feed intake on luteinizing hormone patterns in growthrestricted lambs? Biol. Reprod., 46: 573-579.

Hammerl, J., 1986. Der Einfluß der Aminosaure LTyrosin, als ein Katecholamin-Vorlaufer, auf die Reproduktion bei Ku" hen. In: Proc. $14^{\text {th }}$ World Cong. on Diseases of Cattle. Vol 2. p 911. Dublin, U.K.

Hammerl, J., and M. Russe, 1987a. Der Einfluß der Aminosauren L-Tyrosin und L-Tryptophan auf das Fruchtbarkeitsgeschehen bei jungen Ratten. Zuchthygiene (Berl.) 22:80-84.

Hammerl, J., and M. Russe, 1987b. Reproduktionssteigerung bei Sauen durch perorale Verabreichung von L-Tyrosin. Tieraerztl. Umsch. 42: 551-554.

Hammerl, J., and P. Muller, 1988. Untersuchungen uber den Effekt von Dosis und Applikationszeitpunkt von L-Tyrosin auf das Reproduktionsgeschehen der Ratte. Tieraerztl. Umsch. 43: 450-453.

Helbig, L., M.R. Woodbury, J.C. Haigh and A.D. Barth (2007). The onset of puberty in North American bison (Bison bison) bulls. Anim. Reprod. Sci., 97: 12-24.

Ho, H.C. and S.S. Suarez, 2001. Hyperactivation of mammalian spermatozoa function and regulation. Reprod. 122: 519-526.

Kulanand J., and S. Shivaji, 2001. Capacitationassociated changes in protein tyrosine phosphorylation hyperactivaaaation and acrosome reaction in hamster spermatozoa. Andrologia, 33: 95-104.

Lunstra, D.D. and S.E. Echternkamp, 1982. Puberty in beef bulls: acrosome morphology and semen quality in bulls of different breeds. J. Anim. Sci.,0 55: 638-648.

McCarthy, M.S., H.D. Hafs and E.M. Convey, 1979. Serum hormone patterns associated with growth and sexual development in bulls. J. Anim. Sci., 49: 1012-1020.

Muller, P., 1973. Nervous control of growth hormone secretion. Neuroendocrinol., 11: 338-369.

Munsterer, P., 1987. Zur Anwendung der Aminosa ure L-Tyrosin in der Sterilitatsbehandlung des Milchrindes. Vet. Dissertation. Univ. of Munich, Germany.

Nagatsu T., M. Levitt and S. Udenfriend, 1964. Tyrosine hydroxylase: the initial step in norepinephrine biosynthesis. J. Biol. Chem., 239:2910. 
Noseir W.M.B., M.Y.A. Abboud, G.A. Amrawi, and T.M.E. Lotfy, 2007. Effect of Administration of L-Tyrosine and L-Carnitine on Onset of Puberty in Rabbits. Veterinary Medical Journal, Giza. Vol. 55, No. 4: 1111-1122.

Perez-Pe R., P. Grasa, M. Fernandez-Juan, M.L. Peleato, J.A. Cebrian-Perez and T. MuinoBlanco, 2002. Seminal plasma proteins reduce protein tyrosine phosphorylation in the plasma membrane of cold-shocked ram spermatozoa. Molecular Reproduction and Development 61226-233.

Ramirez, V.D., H.H. Feder, and C.H. Sawyer, 1984. The role of brain catecholamines in the regulation of LH secretion: A critical inquiry. In: L. Martini and W. F. Ganong (Ed.) Frontiers in Neuroendocrinology (Vol. 8). p 27. Raven Press, New York.

Salisbury, G.W., N.L. Vav denmark and J.R. Lodge, 1978. Management factors that affect the reproductive efficiency of the cow, Physiology of Reproduction and Artificial Insemination of Cattle. Freeman, San Francisco, CA 680-732.

Schams, D., E. Schallenberger, S. Gombe and H. Karg, 1981. Endocrine patterns associated with puberty in male and female cattle. J. Reprod. Fertil. Suppl., 30: 103-110.

Saad M.F., M.E. Omara, and S.A. Nahmoud, 2005. Improvement of performance of New Zealand
Rabbit bucks by L-tyrosine. Third Scientific conference, Ras. Sedr, 28-31, July 2005.

Snedecor, G. W. and W. G. Cochran, 1980. Statistical methods., $7^{\text {th }}$ Ed. Allied Pacific, Bomobay.

Terasawa, E., C. Krook, D. L. Hei, M. Gearing, N. J. Schultz, and G.A. Davis, 1988. Norepinephrine is a possible neurotransmitter stimulating pulsatile release of luteinizing hormone releasing hormone in the rhesus monkey. Endocrinology 123:18081816.

Wetzel, G., 1985. Der Einfluß der Aminosaure LTyrosin auf das Fruchtbarkeitsgeschehen beim Rind. Vet. Dissertation. Univ. of Munich, Germany.

Wolf, F.R., J.O. Almquist and E.B. Hale, 1965. Pubertal behaviour and pubertal characteristics of beef bulls on high nutrition allowance. J. Anim. Sci., 24 :761-765.

Wurtman, R.J., F. Hefti, and E. Melamed, 1981. Precursor control of neurotransmitter synthesis. Pharmacol. Rev. 32:315-335.

\title{
تأثير التيروسين علي النمو و البلوغ الجنسي وجودة السائل المنوى ومستوى هرمون التستوستيرون فى عجول الفريزيان
}

\author{
محمد عوض أبو الحمد، محمود سيد صياح \\ معهُ بحوثِ الإتتاج الحبيوانس، مركز البحوث الزراعية، وزارة الزراعة، دقى، مصر
}

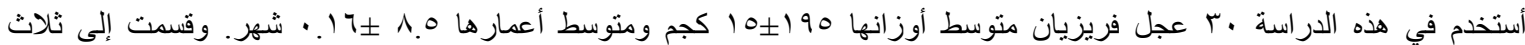

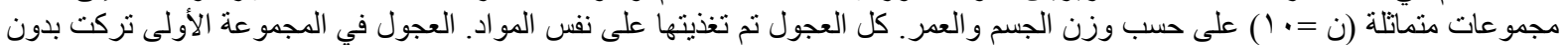

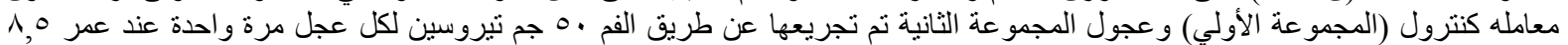

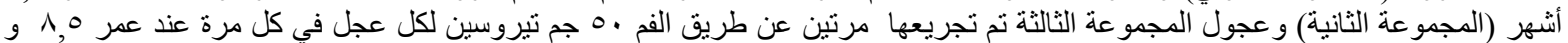
(المجمو عة الثالثة).

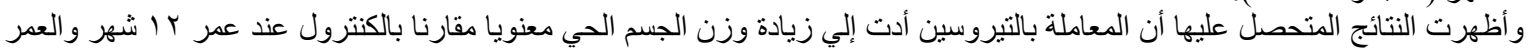

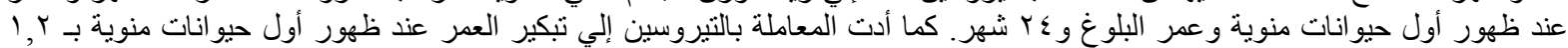

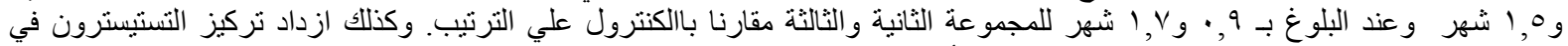

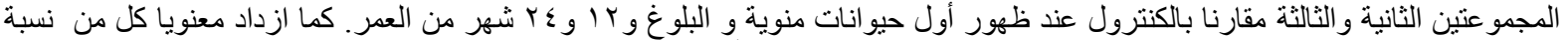

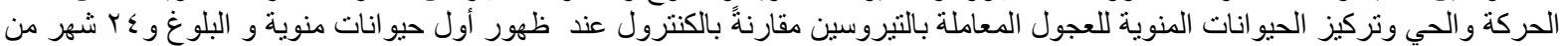

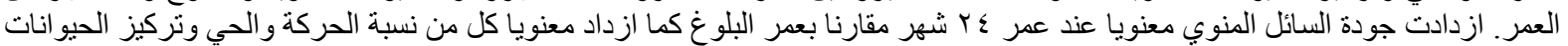

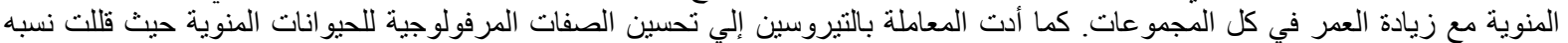

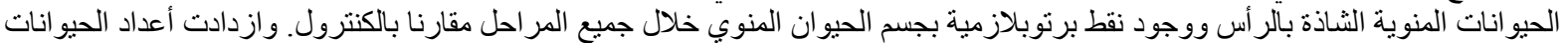

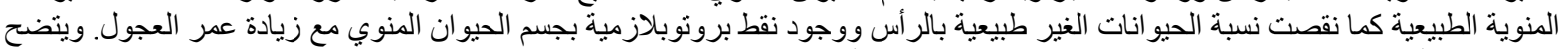

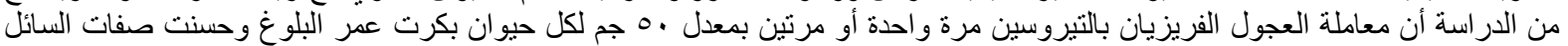

